\title{
Relationship between agro-ecological resources of vineyards and the anthocyanins complex in berries
}

\author{
Elena Ostroukhova ${ }^{1,}$, Evgeniy Rybalko ${ }^{1}$, Svetlana Levchenko ${ }^{1}$, Vladimir Boyko ${ }^{1}$, Dmitriy Belash $^{1}$, and Mariia Viugina $^{1}$ \\ ${ }^{1}$ All-Russian National Research Institute of Viticulture and Winemaking "Magarach" of the RAS, Russian Federation
}

\begin{abstract}
This article is aimed at identifying the relationship between the territories agro-ecological conditions and the anthocyanins complex formation of grapes, which determines the quality and biological value of red wines. Using HPLC, the anthocyanins complex of 'Cabernet Sauvignon' cultivar from 6 industrial vineyards, located in three natural regions of Crimea, was studied. The agro-climatic resources of vineyards were assessed using the methods of geoinformation and mathematical modeling. It was detected that according to parameters of heat and moisture supply vineyards discriminated with Wilks L. $=0.007$; $\alpha<0.00001$. The direct correlation $(\mathrm{r}=0.88-0.95)$ was identified between growing degree days above $10{ }^{\circ} \mathrm{C}$, growing degree days above $20{ }^{\circ} \mathrm{C}$, Winkler index, average growing season temperature and the rate of monoglucosides of malvidin and its derivatives in anthocyanins complex of berries; the inverse correlationbetween the same agroecological indexes and the rate of cyanidin, petunidin and their derivatives. The similarity $(E d=2.79-2.98)$ of anthocyanins complex of grapes from Villino v., Uglovoe v. and Yalta $t$. located in the western foothill-coastal and south coast regions was discovered. The highest content of anthocyanins was found in grapes from Privetnoe v. $\left(5487 \pm 384 \mathrm{mg} \mathrm{kg}^{-1}\right)$, the smallest - from Solnechnaya Dolina v. $\left(2154 \pm 129 \mathrm{mg} \mathrm{kg}^{-1}\right)$ located in the same natural region. The results obtained indicate the need for a "point" assessment of the agro-ecological resources for creation of industrial vineyards.
\end{abstract}

\section{Introduction}

Modern consumer demands for high quality wines are based not only on the unique organoleptic characteristics of wines, but also on their compliance with the physiological needs of the human health. In the case of red wines, anthocyanins play a significant role in formation of these aspects of quality. On the one hand, anthocyanins are responsible for the intensity, shade, and color stability of wines $[1,2]$. On the other hand, in the human health anthocyanins exhibit strong antioxidant properties, determining a wide range of their biological effects: cardioprotective, antitoxic, anti-inflammatory, antiviral, anticarcinogenic, improving the elasticity of blood vessels, visual acuity, etc. [3, 4, 5, 6, 7]. The level of antioxidant activity of anthocyanins is determined by their structure, especially the number of hydroxyl groups in the $\mathrm{B}$ ring and their position, also by the nature of the glycoside, and etc $[5,8,9]$.

Grape berries are the only source of anthocyanins in wine. Anthocyanins are secondary plant cell metabolites; their biosynthesis is interrelated with sugars accumulation during the ripening of grapes. The closest precursors of anthocyanins are flavonons (monoglucosides of cyanidin and delphinidin are primarily formed); their further modification by adding a methyl group leads to the formation of monoglucosides of peonidin, petunidin and malvidin $[9,10]$. The level of sugars required to start anthocyanins synthesis and anthocyanin complex formation are determined by the species and cultivar of grapes: Vitis vinifera at the stage of maturity is characterized by a prevalence of malvidin$3-O-\beta-D$-glucoside and its derivatives, which are the final metabolites of the chain of transformation of anthocyanin compounds [11, 12, 13, 14, 15].

The main function of anthocyanins in plant metabolism is to protect it from harmful environmental influences. Anthocyanins protect the plant's photosynthetic apparatus and DNA under UV-B radiation, reduce oxidative stress by neutralizing nitrogen and oxygen radicals [3, 16, 17]. The biosynthesis of anthocyanins is stimulated under the influence of stress factors. In grapes an increase in the anthocyanin content can be caused by a high level of insolation of plants, a deficiency of moisture or phosphates in the soil, frost during the growing season. On the contrary, an excess of nitrogen in the soil and temperature above $30^{\circ} \mathrm{C}$ inhibit the biosynthesis of anthocyanins $[17,18,19,20,21]$. The variability of the anthocyanin complex under the influence of natural and anthropogenic factors is determined by the grape variety $[10,22,23]$.

Hence, the study of the agroecological parameters of viticultural territories and the identification of their relationship with the formation of anthocyanin complex of berries is an indispensable condition to produce red wine with the desired quality and biological value. In this work, these studies were carried out for industrial

\footnotetext{
* Corresponding author: svelevchenko@,rambler.ru
} 
vineyards of the 'Cabernet Sauvignon' variety located on the Crimean Peninsula.

\section{Materials and methods}

\subsection{Vineyards}

Vineyards of 'Cabernet Sauvignon' are located indifferent geographical objects: next to Yalta town in the south coast region; in Privetnoe village, Morskoe village and Solnechnaya Dolina village in the mountainvalley coastal region; in Vilino village and Uglovoe village in the western foothill-coastal region. Figure 1 shows that vineyards are differ in morphometric parameters of the relief: absolute height above sea level, steepness and aspect of the slope, relative elevation over thalweg. The agricultural technologies used in the vineyards correspond to the technological map for the area.

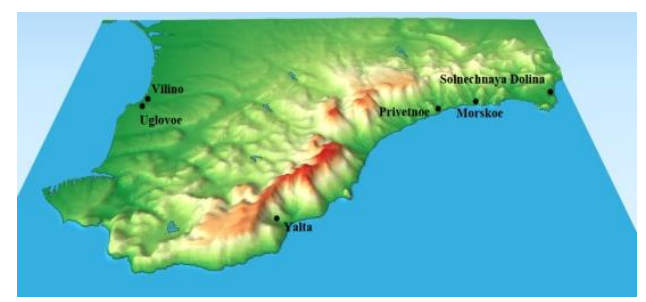

Fig. 1. The location of the analyzed vineyards on the Crimea.

\subsection{Methods for determining the agro-ecological parameters of vineyards}

The first stage of assessing the agro-ecological resources of vineyards included the determination of vineyards geographical coordinates, their orographic and hydrological parameters, and soil cover features. At the second stage, climatic parameters were calculated at the point of vineyards location using data from Crimean stationary weather stations for 2017-2020, digital elevation models SRTM-3, ASTER GDEM and global climate model World clim ver. 2.0. The generally accepted geoinformation models and mathematical models developed by the authors were used to describe the patterns of spatial variation of climatic indicators under the influence of orographic, hydrological and geographical parameters of the analyzed territory [21, 24, 25].

For each vineyard, the following parameters were defined: growing degree days above $10^{\circ} \mathrm{C}\left(\sum \mathrm{T}{ }^{\circ} \mathrm{C} 10\right)$, growing degree days above $20^{\circ} \mathrm{C}\left(\sum \mathrm{T}^{\circ} \mathrm{C} 20\right)$, Huglin index, Winkler index, average growing season temperature ( $\mathrm{t}$ growing ${ }^{\circ} \mathrm{C}$ ), average September temperature $\left(\mathrm{t} \operatorname{Sept}^{\circ} \mathrm{C}\right)$, ratio $\sum \mathrm{T}^{\circ} \mathrm{C} 20 / \sum \mathrm{T}^{\circ} \mathrm{C} 10$, total precipitation during the year $(\mathrm{P}$ year $)$, total precipitation during the growing season ( $\mathrm{P}$ growing), total precipitation in September (P Sept), Selyaninov hydrothermal coefficient (HTC), which is the ratio of the total precipitation during the growing season period increased by 10 times to growing degree days above $10^{\circ}$ C $[26,27]$.

\subsection{Grape samples and analysis methods}

The grape sampling was carried out at the vineyards during the industrial harvest. Samples were transported immediately to the laboratory for analysis.

The content and composition of the anthocyanins complex of berries skin were determined by HPLC. Sample preparation and analysis were performed in accordance by method described in [13]. A Shimadzu LC20 Prominence HPLC system (Japan) equipped with a Nucleosil C18AB column (Macherey - Nagel, Germany) $250 \mathrm{~mm}$ long, $2.0 \mathrm{~mm}$ in diameter, filled with a reversed-phase sorbent (particle size $5 \mu \mathrm{m}$, porosity $100 \AA$ ) and a spectrophotometric detector with diode matrix was used. Oenin chloride (Fluka Chemie AG, Switzerland) was used as a standard.

Total sugars in grapes were determined by areometric method, titrated acids in terms of tartaric acid were determined by titrimetric method [28].

\subsection{Statistical analysis of the data}

The total number of grape samples was 16 . All chemical analyses were performed in 2-3 replications. The data were processed by variance (ANOVA), discriminative (Wilks statistics) and cluster (Euclidean distances - Ed) analysis using Statistics 10 program.

\section{Results and discussions}

The results of determining the climatic parameters of 'Cabernet Sauvignon' vineyards both by geoinformation and mathematical modeling in a 4-year retrospective and their statistical processing are presented in Table 1.

These data indicate that the geographical location of the vineyards caused the dispersion most heat supply parameters during study period at the significance level $\alpha<0.0001$ (for Huglin index $\alpha<0.01$ ). Ratio $\sum \mathrm{T}^{\circ} \mathrm{C} 20 /$ $\sum \mathrm{T}^{\circ} \mathrm{C} 10$ varied in the range $0.52-0.74$ and did not differ significantly across vineyards. The highest heat supply was characterized for vineyards located in the mountainvalley seaside region: the values of indicators in Privetnoe v., Morskoe v. and Solnechnaya Dolina v. on average 5\% (Huglin index) - 21\% (Winkler index) exceeded those for vineyards located in the western foothill-seaside region. The hierarchical classification showed that in terms of heat supply vineyards from the south coast region (Yalta t.) were close to the vineyards from the mountain-valley seaside of the region and significantly differed only by a lower (1.1 times) average September temperature.

The highest annual precipitation during study period was in the vineyard located in Yalta $t$., and on average was $18 \%$ higher than in the western foothill-seaside region vineyards and $43 \%$ higher than in the mountainvalley seaside region vineyards. At the same time, the moisture availability of vineyard areas during the growing season, as well as the Selyaninov hydrothermal coefficient, were the highest in Villino v. and Uglovoe v. The interannual variance of total precipitation in 
Table 1. Values ${ }^{1}$ of climatic parameters of 'Cabernet Sauvignon' vineyards.

\begin{tabular}{|c|c|c|c|c|c|c|c|}
\hline \multirow{4}{*}{ Index } & \multicolumn{6}{|c|}{ Naturalzone / viticultureregion / geographical location } & \multirow{4}{*}{$<\alpha^{2}$} \\
\hline & \multirow{2}{*}{\multicolumn{2}{|c|}{$\begin{array}{c}\text { Foothill zone } \\
\begin{array}{c}\text { Western foothill-seaside } \\
\text { region }\end{array}\end{array}$}} & \multicolumn{4}{|c|}{ South coast zone } & \\
\hline & & & \multirow{2}{*}{$\begin{array}{c}\begin{array}{c}\text { South coast } \\
\text { region }\end{array} \\
\text { Yalta }\end{array}$} & \multicolumn{3}{|c|}{ mountain-valleyseasideregion } & \\
\hline & Villino & Uglovoe & & Privetnoe & Morskoe & $\begin{array}{c}\text { Solnechnaya } \\
\text { Dolina }\end{array}$ & \\
\hline$\sum \mathrm{T}^{\circ} \mathrm{C}_{10}$ & $3912 \pm 199$ & $3831 \pm 199$ & $4199 \pm 381$ & $4385 \pm 159$ & $4432 \pm 159$ & $\begin{array}{l}4396 \\
\pm 159 \\
\end{array}$ & 0.0001 \\
\hline$\sum \mathrm{T}^{\circ} \mathrm{C}_{20}$ & $2274 \pm 247$ & $2201 \pm 247$ & $2584 \pm 144$ & $2740 \pm 146$ & $2754 \pm 146$ & $\begin{array}{l}2723 \\
\pm 146\end{array}$ & 0.0001 \\
\hline Huglin index & $2241 \pm 83$ & $2197 \pm 68$ & $2430 \pm 112$ & $2303 \pm 132$ & $2342 \pm 132$ & $\begin{array}{l}2336 \\
\pm 132\end{array}$ & 0.01 \\
\hline Winklerindex & $1795 \pm 109$ & $1756 \pm 109$ & $2128 \pm 114$ & $2148 \pm 148$ & $2169 \pm 148$ & $\begin{array}{l}2151 \\
\pm 148\end{array}$ & 0.0001 \\
\hline T sept ${ }^{\circ} \mathrm{C}$ & $\begin{array}{r}18.8 \\
\pm 1.1 \\
\end{array}$ & $\begin{array}{r}18.3 \\
\pm 1.1 \\
\end{array}$ & $\begin{array}{l}18.6 \\
\pm 1.5 \\
\end{array}$ & $\begin{array}{c}21 . \\
1 \pm 1.0\end{array}$ & $\begin{array}{l}20.9 \\
\pm 1.0 \\
\end{array}$ & $\begin{array}{l}21.2 \\
\pm 1.0 \\
\end{array}$ & 0.0001 \\
\hline $\mathrm{T}$ growing ${ }^{\circ} \mathrm{C}$ & $\begin{array}{l}19.2 \\
\pm 0.6\end{array}$ & $\begin{array}{l}19.1 \\
\pm 0.6\end{array}$ & $\begin{array}{l}20.2 \\
\pm 0.6\end{array}$ & $\begin{array}{l}20.9 \\
\pm 0.7\end{array}$ & $\begin{array}{l}20.9 \\
\pm 0.7\end{array}$ & $\begin{array}{l}20.9 \\
\pm 0.7\end{array}$ & 0.0001 \\
\hline$\sum \mathrm{T}^{\circ} \mathrm{C}_{20} / \sum \mathrm{T}^{\circ} \mathrm{C}_{10}$ & $\begin{array}{c}0.58 \\
\pm 0.05\end{array}$ & $\begin{array}{c}0.57 \\
\pm 0.05\end{array}$ & $\begin{array}{c}0.62 \\
\pm 0.08\end{array}$ & $\begin{array}{c}0.62 \\
\pm 0.02\end{array}$ & $\begin{array}{c}0.62 \\
\pm 0.02\end{array}$ & $\begin{array}{c}0.62 \\
\pm 0.02\end{array}$ & 0.1 \\
\hline HTC & $\begin{array}{c}0.75 \\
\pm 0.15 \\
\end{array}$ & $\begin{array}{c}0.77 \\
\pm 0.15 \\
\end{array}$ & $\begin{array}{c}0.66 \\
\pm 0.10 \\
\end{array}$ & $\begin{array}{c}0.49 \\
\pm 0.17 \\
\end{array}$ & $\begin{array}{c}0.47 \\
\pm 0.17 \\
\end{array}$ & $\begin{array}{c}0.48 \\
\pm 0.17 \\
\end{array}$ & 0.002 \\
\hline $\mathrm{P}_{\text {year }}, \mathrm{mm}$ & $\begin{array}{l}455 \\
\pm 53\end{array}$ & $\begin{array}{l}465 \\
\pm 53\end{array}$ & $\begin{array}{c}544 \\
\pm 157\end{array}$ & $\begin{array}{c}392 \\
\pm 102\end{array}$ & $\begin{array}{c}381 \\
\pm 102\end{array}$ & $\begin{array}{c}368 \\
\pm 102\end{array}$ & 0.02 \\
\hline $\mathrm{P}_{\text {growing }}, \mathrm{mm}$ & $\begin{array}{l}291 \\
\pm 43\end{array}$ & $\begin{array}{l}295 \\
\pm 43\end{array}$ & $\begin{array}{l}268 \\
\pm 56\end{array}$ & $\begin{array}{l}209 \\
\pm 65\end{array}$ & $\begin{array}{l}206 \\
\pm 65\end{array}$ & $\begin{array}{l}206 \\
\pm 65 \\
\end{array}$ & 0.006 \\
\hline$P_{\text {Sept }}, \mathrm{mm}$ & $\begin{array}{c}33.1 \\
\pm 30.8\end{array}$ & $\begin{array}{c}33.9 \\
\pm 31.2\end{array}$ & $\begin{array}{c}48.2 \\
\pm 62.0\end{array}$ & $\begin{array}{c}25.0 \\
\pm 16.0\end{array}$ & $\begin{array}{c}24.0 \\
\pm 16.0\end{array}$ & $\begin{array}{c}28.0 \\
\pm 16.0\end{array}$ & 0.5 \\
\hline
\end{tabular}

September exceeded the territorial variance of the indicator. So, in September 2017, there was no precipitation at all in the western foothill-seaside vineyards, in 2018 precipitation was maximum and amounted to 71-72 $\mathrm{mm}$. During same years variation range of total precipitation in vineyards located in Yalta t. ranged from 5.4 to $140.0 \mathrm{~mm}$. The variation range of total precipitation in September in the mountain-valley seaside region was from 7.8 to $48.0 \mathrm{~mm}$.

It was detected that according to parameters of heat (except for $\sum \mathrm{T}^{\circ} \mathrm{C} 20 / \sum \mathrm{T}^{\circ} \mathrm{C} 10$ ) and moisture supply (except $\mathrm{P}_{\text {Sept }}$ and $\mathrm{P}_{\text {year }}$ ), vineyards discriminated with Wilks L. $=0.007 ; \alpha<0.00001$.

Differences in climatic parameters in vineyards due to their geographical location, orographic and hydrological characteristics of the territories, which influence the formation of the phenolic complex of berries, have been established. Samples of 'Cabernet Sauvignon' obtained from the investigated vineyards were characterized by the sugar content from 19.1 to $21.8^{\circ}$ Brix, titratable acids - from 4.2 to $6.6 \mathrm{~g} / \mathrm{dm}^{3}$. Results of the analysis of the anthocyanins complex of the grape skins are presented at Table 2. It is known that the formation of anthocyanins complex in grapes is interrelated with the accumulation of sugars [9, 10]. However, statistical processing of the available data set did not reveal the significance of the sugar content in the specified interval in the variance of the quantitative content and qualitative composition of anthocyanins.
The total content of identified anthocyanins in grapes obtained from various vineyards varied from $2154 \pm 129$ mg kg-1 (Solnechnaya Dolina v.) to $5487 \pm 384 \mathrm{mg} \mathrm{kg-1}$ (Privetnoe v.) (Table 2). The share of monoglucosides of anthocyanins ranged from $52 \%$ in grapes from Privetnoe v. up to $72 \%$ - from Solnechnaya Dolina v. The content of derivatives of monoglucosides acylated by acetic acid was from $18 \%$ (Villino v. and Solnechnaya Dolina v.) to $39 \%$ (Privetnoe v.), of their derivatives acylated by $\mathrm{p}$ coumaric acid - from 9\% (Uglovoe v. and Solnechnaya Dolina v.) to $14 \%$ (Villino v.). 
Table 2. The content* (average, $\mathrm{mg} \mathrm{kg}^{-1}$ ) of anthocyanins in'Cabernet Sauvignon' berries skin from different vineyards.

\begin{tabular}{|c|c|c|c|c|c|c|}
\hline \multirow[b]{2}{*}{ Index } & \multicolumn{6}{|c|}{ Geographical location } \\
\hline & $\begin{array}{c}\text { Villin } \\
\mathrm{o}\end{array}$ & $\begin{array}{c}\text { Uglovo } \\
\mathrm{e}\end{array}$ & Yalta & $\begin{array}{c}\text { Privetn } \\
\text { oe }\end{array}$ & $\begin{array}{c}\text { Morsko } \\
\mathrm{e}\end{array}$ & $\begin{array}{c}\text { Solnechna } \\
\text { ya } \\
\text { Dolina } \\
\end{array}$ \\
\hline $\begin{array}{l}\text { Delphinidi } \\
\text { n-3-O- } \beta \text { - } \\
\text { D- } \\
\text { glucoside }\end{array}$ & 264.5 & 297.7 & 470.0 & 491.2 & 358.2 & 146.5 \\
\hline $\begin{array}{l}\text { Cyanidin- } \\
\text { 3-O- } \beta \text {-D- } \\
\text { glucoside }\end{array}$ & 54.0 & 45.7 & 55.8 & 80.7 & 79.3 & 21.1 \\
\hline $\begin{array}{l}\text { Petunidin- } \\
3 \text {-O- } \beta \text {-D- } \\
\text { glucoside }\end{array}$ & 225.9 & 247.0 & 302.9 & 304.7 & 293.2 & 134.9 \\
\hline $\begin{array}{l}\text { Peonidin- } \\
3 \text {-O- } \beta \text {-D- } \\
\text { glucoside }\end{array}$ & 143.3 & 94.8 & 135.5 & 31.5 & 188.9 & 72.5 \\
\hline $\begin{array}{l}\text { Malvidin- } \\
\text { 3-O- } \beta \text {-D- } \\
\text { glucoside }\end{array}$ & $\begin{array}{c}1243 . \\
1\end{array}$ & 1473.1 & $\begin{array}{c}1718 \\
9\end{array}$ & 1942.4 & 1501.3 & 1181.0 \\
\hline $\begin{array}{l}\text { Delphinidi } \\
\mathrm{n}-3-\mathrm{O}-\beta- \\
\mathrm{D}- \\
\text { glucoside- } \\
\text { 6-O- } \\
\text { acetate }\end{array}$ & 63.1 & 91.3 & 112.9 & 121.7 & 75.8 & 27.6 \\
\hline $\begin{array}{l}\text { Cyanidin- } \\
\text { 3-O- } \beta \text {-D- } \\
\text { glucoside- } \\
\text { 6-O- } \\
\text { acetate }\end{array}$ & 23.3 & 43.0 & 22.4 & 31.2 & 22.9 & 7.1 \\
\hline $\begin{array}{l}\text { Petunidin- } \\
\text { 3-O- } \beta \text {-D- } \\
\text { glucoside- } \\
\text { 6-O- } \\
\text { acetate }\end{array}$ & 65.8 & 70.8 & 127.3 & 148.1 & 105.4 & 37.3 \\
\hline $\begin{array}{l}\text { Peonidin- } \\
\text { 3-O- } \beta \text {-D- } \\
\text { glucoside- } \\
6 \text {-O- } \\
\text { acetate }\end{array}$ & 15.4 & 12.6 & 1.3 & 1.6 & 3.4 & 1.9 \\
\hline $\begin{array}{l}\text { Malvidin- } \\
\text { 3-O- } \beta \text {-D- } \\
\text { glucoside- } \\
6 \text {-O- } \\
\text { acetate }\end{array}$ & 338.7 & 371.0 & $\begin{array}{c}1192 . \\
3\end{array}$ & 1813.7 & 601.2 & 321.9 \\
\hline $\begin{array}{l}\text { Petunidin- } \\
\text { 3-O- } \beta \text {-D- } \\
\text { glucoside- } \\
6 \text {-O- } p \text { - } \\
\text { coumarate }\end{array}$ & 42.4 & 28.0 & 30.8 & 59.9 & 52.3 & 47.4 \\
\hline $\begin{array}{l}\text { Malvidin- } \\
\text { 3-O- } \beta \text {-D- } \\
\text { glucoside- } \\
6 \text {-O- } p \text { - } \\
\text { coumarate }\end{array}$ & 361.9 & 238.4 & 405.9 & 459.9 & 420.9 & 154.8 \\
\hline $\begin{array}{l}\text { Sum of } \\
\text { anthocyani } \\
n s\end{array}$ & 2842 & 3013 & 4576 & 5487 & 3703 & 2154 \\
\hline
\end{tabular}

*standard deviation was no more than $10 \%$ of the mean values of the content of the components

The anthocyanins complex was dominated by malvidin-3-O- $\beta$-D-glucoside and its derivatives (Figure 1). The largest proportion of components (77\%) was noted in grapes from Privetnoe v. and Solnechnaya Dolina v.; the lowest (68-69\%) - in grapes from the western foothill-seaside region and from Morskoe v. The direct correlation $(r=0.88-0.95 ; \alpha<0.05)$ was identified between the rate of monoglucosides of malvidin and its derivatives in anthocyanins complex and growing degree days above $10{ }^{\circ} \mathrm{C}$, growing degree days above $20{ }^{\circ} \mathrm{C}$, Winkler index, average growing season temperature characteristic of vineyard areas.

On the contrary, the proportion of cyanidin and petunidin and their derivatives was inversely correlated $(\mathrm{r}=0.89-0.93 ; \alpha<0.05)$ with the parameters of heat supply in vineyards: $\sum \mathrm{T}^{\circ} \mathrm{C} 10$, Winkler index, average growing season temperature. The smallest proportion of cyanidins $(\leq 2 \%)$ and petunidins $(\leq 10 \%)$ was noted in grapes from Privetnoe v., Solnechnaya Dolina v. and Yalta t. There was a close inverse correlation between the proportion of monoglycosides malvidin and petunidin (including their derivatives) in the complex of anthocyanins in the berries skin $(r=0.90 ; \alpha<0.05)$, which is explained by the fact that in the process of biosynthesis they are formed from one precursor, delphinidin-3-O - $\beta$-D-glucoside [9, 10]. It was revealed that the proportion of monoglycoside delphinidin and its derivatives in the anthocyanins complex was the higher, the lower the total precipitation during the growing season $(\mathrm{r}=-0.80)$ and the Selyaninov hydrothermal coefficient were $(r=-0.83)$. Accordingly, the share of monoglucosides malvidin and its derivatives directly correlated $(\mathrm{r}=0.88-0.98)$ with these indicators of moisture availability in vineyards. The revealed relationship between the composition of grape anthocyanins complex and climatic parameters is important in determining the viticultural territories in order to obtain raw materials for wine products enriched with antioxidants: monoglucosides of delphinidin and cyanidin have the greatest antioxidant activity among anthocyanins found in plants $[8,9]$.

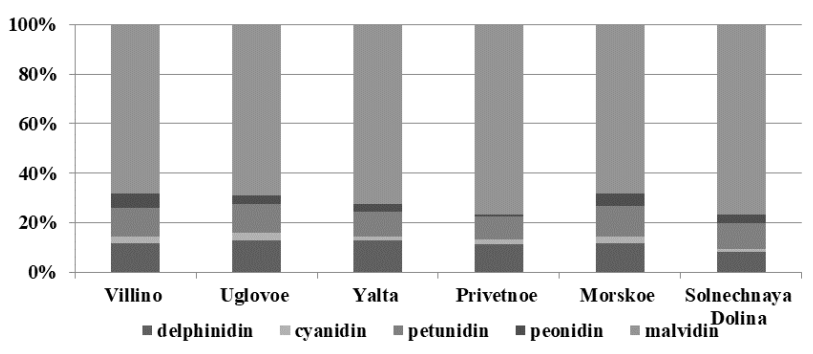

Fig. 1. Composition (\%) of a complex of anthocyanins monoglucosides and their derivatives in 'Cabernet Sauvignon' skin berries from different vineyards.

Correlation between the proportion of monoglycoside of peonidin and its derivatives in the anthocyanin complex and the parameters of heat and moisture supply in vineyards was not found. At the same time, an average level of correlation $(r=0.77-0.80)$ was noted between the accumulation of monoglucosides of peonidin and total precipitation during the growing season and the Selyaninov hydrothermal coefficient.

As a result of the multidirectional influence of climatic conditions on the anthocyanins formation in 
berries, the greatest similarity of the anthocyanin complex was revealed for grapes obtained in the vineyards of Villino v. and Uglovoe v. - the standardized Euclidean distance (Ed) is 2.79, as well as Yalta t. and Morskoe v. - $\mathrm{Ed}=2.98$ (Figure 2). Special attention should be paid to the fact that the quantitative content of anthocyanins in grapes from Solnechnaya Dolina v. significantly differed from that in the samples from other vineyards from the mountain-valley seaside region, characterized by close values of the analyzed climatic parameters. Perhaps this was due to the use of drip irrigation of plants in Solnechnaya Dolina v., low relative air humidity observed over the last 3 years, soil composition and characteristics of the agricultural technology system $[19,20,22,23]$. It seems advisable to conduct further research in this direction.

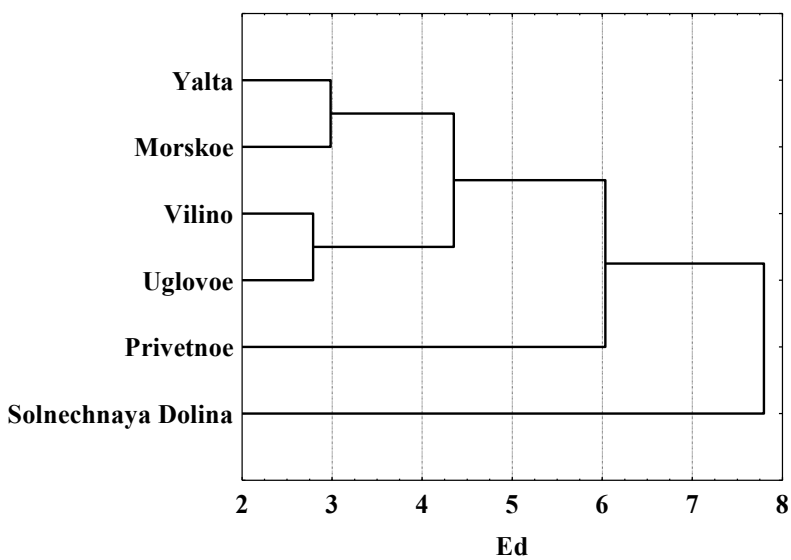

Fig. 2. The results of the cluster analysis of different vineyards based on the anthocyanins complex in 'Cabernet Sauvignon' skin.

\section{Conclusion}

The studies have shown that zoning of ampeloecological resources of territories on the basis of identifying and geoinformation modeling of the relationships between the spatial distribution of climatic characteristics and metabolites of the grape plant is an indispensable stage in the creation of wines with the desired organoleptic quality and biologically active properties. On the example of six vineyards of cv. 'Cabernet Sauvignon' in Crimea, the most informative climatic parameters have been identified that discriminate against territories with different orographic and hydrological characteristics. A multidirectional correlation $(\mathrm{r}=/ 0.88-0.95 / ; \alpha<0.05)$ has been revealed between the indicators of heat and moisture supply in vineyards, on the one hand, and the qualitative composition and quantitative content of anthocyanins complex in grapes, on the other hand. Using hierarchical classification, the level of similarity difference between anthocyanins complex grapes from different vineyards has been determined. The possibility of differentiating the anthocyanin complex of grapes from vineyards located in the same natural region is shown. This fact indicates a need for a "point" assessment of the agro-ecological resources for creation of industrial vineyards.

Financial source: the reported study was funded by RFBR, project number 20-016-00075

\section{References}

1. F. He, N.N. Liang, L. Mu, Q.H. Pan, J. Wang, M.J. Reeves, C-Q. Duan, Molecules, 17, 15711601 (2012)

2. F. He, N.N. Liang, L. Mu, Q.H. Pan, J. Wang, M.J. Reeves, C-Q. Duan, Molecules, 17 (2), 1483-1519 (2012)

3. O. Vicente, M. Boscaiu, Not Bot HortiAgrobo, 46 (1), 14-21 (2018)

4. N. Tena, J. Martin, A.G. Asuero, Antioxidants, 9, 451 (2020)

5. J. Martin, E.M. Kuskoski, M.J. Navas, A.G. Asuero, Flavonoids - From Biosynthesis to Human Health, Chapter 11 (Open Access Publisher: Rijeka, Croatia, 2017, 205-255)

6. Y. Nomi, K. Iwasaki-Kurashige, H. Matsumoto, Therapeutic effects of anthocyanins for vision and eye health. Molecules, 24 (18), 3311 (2019)

7. M.E. Eker, K. Aaby, I. Budic-Leto, S. Rimac Bencic, S.N. El, S. Karakaya, S. Simsek, C. Manach, W. Wiczkowski, S. de Pascual-Teresa, Foods, 9, 2 (2020)

8. H.M. Ali, W. Almagribi, M.N. Al-Rashidi, Food Chem., 194, 1275-1282 (2016)

9. R. Mattioli, A. Francioso, L. Mosca, P. Silva, Molecules, 25, 3809 (2020)

10. A. Teixeira, J. Eiras-Dias, S.D. Castellarin, H. Gerós, Int. J. Mol. Sci., 14, 18711-18739 (2013)

11. L. Narduzzi, J. Stanstrup, F. Mattivi, J. Agric. Food Chem., 63 (30), 6823-6834 (2015)

12. J. Garcia, W. Zheng, P. Balda, F. Martinez de Toda, Vitis, 56, 15-18 (2017)

13. E. Ostroukhova, S. Levchenko, V. Likhovskoi, V. Volynkin, I. Peskova, I. Vasylyk, Acta Horticulturae, 1259, 105-113 (2019)

14. I.V. Peskova, E.V. Ostroukhova, M.A. Vyugina, Magarach, Viticulture and winemaking, 1, 31-33 (2017)

15. M. Kharadze, I. Japaridze, A. Kalandia, M. Vanidze, Annals of Agrarian Science, 16 (2), 181-184 (2018)

16. M.L. Falcone Ferreyra, S.P. Rius, P. Casati, Front Plant Sci., 3, 222 (2012)

17. V. Cheynier, G. Comte, K.M. Davies, V. Lattanzio, S. Martens, Plant Physiology and Biochemistry, 72, 1-20 (2013)

18. F. Lecourieux, C. Kappel, P. Pieri, J. Charon, J. Pillet, G. Hilbert, C. Renaud, E. Gomes, S. Delrot, D. Lecourieux, Front. Plant Sci., 8, 53 (2017)

19. N. Movahed, C. Pastore, A. Cellini, G. Allegro, G. Valentini, S. Zenoni, E. Cavallini, E. D'Incà, G.B. Tornielli, I. Filippetti, J. Plant Res, 129, 513-526 (2016) 
20. C. Pastore, S. Dal Santo, S. Zenoni, N. Movahed, G. Allegro, G. Valentini, I. Filippetti, G.B. Tornielli, Front. Plant Sci., 8, 929 (2017)

21. E. Rybalko, E. Ostroukhova, N. Baranova, I. Peskova, V. Borisova, Horticulture and Viticulture of the South Russia, 66 (6), 149-167 (2020)

22. M. Vilanova, M. Santalla, A. Masa, The Journal of Agricultural Science, 147 (6), 683-697 (2019)

23. E. Stranishevskaya, E. Ostroukhova, I. Peskova, S. Levchenko, E. Matveikina, N. Shadura, E3S Web of Conferences, 161, 01070 (2020)

24. E.A. Rybalko, Magarach, Viticulture and winemaking, 2, 10-11 (2014)

25. E.A. Rybalko, N.V. Baranova, Environmental control systems, 6 (26), 101-105 (2016)

26. E.A. Rybalko, Magarach, Viticulture and Winemaking, 22 (1), 26-28 (2020)

27. G. Jones, ActaHortic., 689, 41-60 (2005)

28. Compendium of international methods of wine and must analysis, Paris (2017). 